\author{
Галя Симеонова-Конах \\ Uniwersytet im. Adama Mickiewicza, Poznań \\ galia_s@poczta.onet.pl
}

\title{
ЗА „БЪЛГАРСКИТЕ МОЗАЙКИ” И КНЯГИНЯ ВЕНЦИСЛАВА-ВИОЛА В ПОЛСКАТА ЛИТЕРАТУРНА И КУЛТУРНА ПАМЕТ
}

В последните десетилетия един от най-важните дискурси в университетските изследвания е паметта като историческа и културна категория. В това понятие са отразени определени тенденции на академическото знание и световната медиевистика, зародили се методологически в средата на XX век в изследванията на учените от Виенската историко-антропологическа школа и нейните последователи в Европа и САЩ. Приетите от тях подходи разполагат историческото знание в широки културни контексти, обединяващи различни области на човешката духовна и материална дейност. Историческата памет се разглежда от редица изследователи релативно, преди всичко като „конструкция“, изградена по правилата на конкретни обществени или държавни стратегии и създавана в определена система на задължителни тълкувания на историческите събития. [Geertz 2005: 49-53] Но така разбирана нейната условност в никакъв случай не е равнозначна с представата за аисторичност, не означава също нито фалшиво, нито неправдиво предаване на събитията, а единствено сигнализира факта на оформяне в резултат на обществени потребности и селекция. В борбата за съхранение на историческата памет символите, свидетелствата и знаците на миналото, техният емоционален заряд, а също и литературните произведения, играят важна роля. В обговаряния дискурс паметта винаги е свързана с идентичността на личността и общността. Обществените фактори, смяната на поколенията, държавата като пазителка на своя символически капитал, поставя под съмнение или подкрепя метанаративите на националната история. Паметта на общността е силна, защото се опира на символически знаци, които запечатват, а преди всичко обобщават и уеднаквяват спомените за историческите събития, предават ги на следващите поколения, споделящи общи възгледи за света и начини за неговото разбиране. Тези символически стълбове, приобщават индивидуалната памет към обществената, подпомагат я чрез по- 
стоянно припомняне и визуализиране в юбилейни годишнини, паметници и ритуали, исторически възстановки, означават и критериите, оформящи колективната памет. Индивидуалната памет в известен смисъл се подчинява на поколенческата, основава се на общия исторически, културен и духовен опит. [Assman 2013: 47-50] Мястото на всеки народ и култура в европейската памет зависи в определена степен и от неговото силно историческо съзнание и активност, от целенасочената културна политика, която способства да се утвърди разказът за историческите събития и местата, свързани с тях.

Каква е паметта за българската история в общоевропейското състезание за трансмисия на националната история, как и доколко фрагменти от българската история или култура са вписани в паметта на друг народ, в случая полския, подобни въпроси бележат най-общия контекст на това изследване. Методологически то се вписва в насоките, очертани от споменатата историко-антропологическа школа, определени епистемиологически и литературни въпроси са ситуирани в рецепцията на чуждата култура. Бях водена и от занимателния изследователски интерес: Какви образи рисуват „българските мозайки“ в чуждата култура, в случая без никакви идейни или политически податки и подкрепа от страна на българската държава за популяризиране на собствената си история.

Представите за българското съм се опитала да проследя в два изследователски аспекта, за които най-общото свързващо звено е българската история. Първият е насочен към поетическото наследство на известни полски творци от 50-те, 60-те и 70-те години на XX век, останали в литературно-поетическата памет на полските читатели, вторият се отнася конкретно към полската културно-историческа памет, осъществяваща се в исторически реконструкции на миналото. Най-популярната фигура от българската история, според моите проучвания, се оказа средновековната търновска княгиня Венцислава-Виола [?-1251], споменът за която под различни форми битува вече десетилетия в регионалната памет на хората от Ополското воеводство. На нейната личност и управление са посветени няколко проучвания в полската историческа наука и културознание, както и един научен спор, състоял се през 80-те години на XX век. Венцислава-Виола е почти неизвестна за широката българска публика, споменавана е от някои български историци [Андреев 1997: 174] във връзка с нейния династичен брак с полския княз Кажимеж I, за което имаме податки в хрониката на средновековния историк Ян Длугош.

Българската тема присъства солидно и интересно в творчеството на редица полски поети от втората половина на XX век. Откриваме я, както в лингвистичната поезия от шейсетте години, в Новата вълна и лириката на поколението Хибриди (Александър Навроцки и други), така и в по-късни поетически реализации. Литературните факти, които привлякоха моето внимание предвид темата на изследването, бяха някои творби на полски поети от края на петдесетте и шейсетте години на XX век и преди всичко цикълът на Тадеуш Ружевич, озаглавен Българска мозайка om 1978 г. (Butgarska mozaika 
z roku 1978), създаден през седемдесетте години. Той е плод на творческия престой на поета в някогашния Творчески дом на писателите в Ситняково, бившата планинска резиденция на цар Фердинанд, но по неизвестни причини Ружевич го публикува двадесет години по-късно в поетическата си книга Винаги фрагмент. Рециклиране (Zawsze fragment; Recycling, 1996). Изключително интересни за мен бяха поетическите конструкти на представите за българското, моделирани посредством чувствителността на лирическия Аз.

Индивидуалните поетически фрагменти на паметта, „българските мозайки“ на Тадеуш Ружевич ни сблъскват с образите на нашето родно в чуждото творческо съзнание (отпращайки ни към тезата на Теодор Адорно, че именно „цялостта е неистина”. Ружевич изтръгва фрагменти от „системата" на българския свят за да обърне внимание на тяхната обособеност, на метафизическата им незавършеност, а едновременно конкретност, придавайки им символически значения. В стихосбирката си Винаги фрагмент. Рециклиране поетът изповядва една особена метафизика, като иронизира собствените си опити за създаване на верига от значения, творящи „цялост“. България във философския дискурс на Тадеуш Ружевич присъства винаги във фрагменти, може би родени от присъщата на българската история накъсаност и необичайното синхронично и диахронично битуване на различни времена и образи. Неговото отношение към страната се проявява от една страна в използвания екзотически код на новооткритата непозната древна земя - страна на камъка, на библейските образи, от друга страна фокусира своето внимание върху превратностите на историята и накърнения исторически континуум, като се има предвид и фактьт, че майчиният език на съвременните български царе е немският. Сблъсъкът на времена, култури, азбуки, представи провокира размислите на автора. Поетическият език на Ружевич е композиран от изрази и фрази на полски, български, немски и сам по себе си е езикова мозайка.

[...] вали дъжд/дъжд вали/и вали/пием хербата/ черен чай/в ловния дворец/на цар Фердинанд/и цар Борис/препариран орел/Erlegt von SR. Kön. Hoheit/Fürst Ferdynand I. von Bulgarien/Rimaszégs 9 XII 1904/Рога на елен/ Erlegtam 21. Januar 1912... [Różewicz 1998: 11]

За Ружевич цитирането и преплитането на езиците не е безгрижна интертекстуална игра, в която означаваното и означаващото са съвършено заменяеми. Деконструкторската свободна игра на разликите и следите, по Дерида [Derrida 1999: 126-136], но и по Ружевич, лишава човека от стабилна почва под краката му, а неговата екзистенция - от цел и смисъл, тя ускорява „края на човека” - в метафизиката отложен безконечно. Този край настьпва в бездната на езика. В бившата царска ловна резиденция на цар Фердинад, а поради превратностите на историята вече Дом на писателите, поетът ясно съзира фрагментирането и противопоставянето на световете, объркването на езиците. Поетически Ружевич структурира подобни проблеми в образи и думи - архаичната древност на България и нейната немска модерна монархия, почти библейския рилски пастир и европейската култура на софийския 
естаблишмент. Същевременно баналността на разговорния език за лирическия Аз е в контраст, но и в дълбоко единство, както с немскоезичните книги и надписи в аристократичния дворец на Кобургите в Рила, така и с универсума на природата. В откъслеците на времето, той е сам в своето усилие да дешифрира битието и историята в тяхната цялост. В поетическия свят на Ружевич България носи знамението на евангелска притча, съвършеният израз на нейната древност е камъкът, прастар и вечен. Поетьт се опитва да стилизира парченцата в мозайки от камъчета, но понякога в тях липсва камъче. Квинтесенцията на България, според него е камъкът. „[...] черно камъче/ бяло камъче/синя раковинка/червено вино/черно камъче/жълто черно/липса на камъче/в мозайката...“ [Różewicz 1998: 12]

Интертекстуалните и интерсемиотични преноси в поезията на Ружевич не служат за засилване на литературността на поетическия език, книгата $B u$ наги фрагмент. Рециклиране не е творба, която бихме зачислили към лингвистическата поезия. Философските внушения и пресъздадените образи носят ценностни значения, боравят с една антихерменевтика, чиито напластявания и неочаквани езикови лабиринти ни отпращат към криволиците и промените в историята, духът на времето и мястото е затворен в силата на фрагментите, чрез които парадоксално поезията улавя живота. В Българска мозайка от 1978 2., автономията на „откъслеците“, алюзиите към другите знаци, не е белязана от свободната игра на значещото. Благодарение на сугестивната поетика на текста, изградена чрез снаждане на цитати, парафрази, пародии, стигаме до извода, че въпреки всичко, пропилял толкова много неща и ценности в съвременността, лирическият Аз не може да се примири със загубата на цялостта. Чрез „българските мозайки“ Ружевич е верен на философските тьрсения на полската поезия, характерни за следвоенното поколение автори. Неговият поетически свят е потопен в антиномиите на битието и словото, на историческите обстоятелства, авторьт е неспособен да ги проумее докрай, познанието е невъзможно поради изключителната разчлененост на представяния свят. Изглежда това поетьт разбира в Рила и Ситняково. От едната страна стои невъзможността, неуспехът на всеки опит за познание, от другата страна е България, която благодарение на уловеното от поета единство на противоположностите е еманация на универсални принципи.

В полската поезия от втората половина на XX век Тадеуш Ружевич не е първооткривател на българското. Преди него, съдейки по творчеството им, България е вдъхновение за цяло поколение полски лирици от 50-те и 60-те години на XX век с миналото си, с античното и средновековно наследство по българските земи, тя е страната на камъка. Именно от тях Ружевич наследява този образ.

Историческата и литературната памет за България, колкото и да са отдалечени по време, смисъл, конкретни реализации, са активизирани в един общ дискурс, а именно - историчността, древността на страната, на нейната култура, представите за тях са разгърнати в съвременната полска поезия. България битува в културната рецепция, в преживяванията и спомените на 
следвоенното поколение на полските интелектуалци и творци, които я посещават по различни поводи. Анна Каменска ${ }^{1}$ се запознава с България, както тя самата споменава, чрез своя съпруг, поетът Ян Шпиевак, „който за първи път след войната посети страната и се върна възхитен от нейните пейзажи, стара култура и народа й““ [Kamieńska 1988: 52].

Рецепцията на българското е обособена не само семантично, но и географски, любими на полските поети райони са Черно море, античните черноморски градове, планините, историческите центрове. Сред тях особено място заема Велико Търново, град, който чрез историческите си забележителности изгражда в творчеството на споменатите автори представата за историчността на страната и нейната култура. В настъпилата „текстуализация“ на действителността през последните декади на XX век, знакът „Европа““ означава преди всички култура, Европа е не само географско, тя е аксиологическо понятие. Един от опитите да се дефинира Европа и да се определи основната същност на понятието европейска култура чрез някакъв основополагащ белег е да се приеме, че тя се отнася към култури, определяеми като исторически, притежаващи история, главната черта на европейското е историчността. Така разбирана, тя е аксиологическа категория, благодарение на която Европа означава история и цивилизация. Понятията Европа-история-цивилизация се изравняват, стават еквивалентни. България е включена в този дискурс на еквивалентността благодарение на своята историчност, античността и средновековието, епохи, които стават белег, знак на нейната древност и принадлежност към европейската култура.

За Ян Шпиевак в Търново „всяка стъпка тук е стъпка на историята“ [Śpiewak 1999: 51]. Почти по същото време, през 1961 г. Ян Зих публикува своята, посветена на старата българска столица, поема Tърново [Zych 1999: 50], Велико Търново е обект на вдъхновение и за друг автор от това поколение - Ян Баранович [Baranowicz 1999: 56]. Срещата с историческото минало за лирическия Аз прелива във философски размисли за тленността на човека, за преминаването на човешкия живот, възприемани в единна верига от значения и образи: живот-сън-тленност-смърт. Полските поети търсят по-широки обобщения на историческото минало и неговите образи, които конфронтират с онтологически въпроси за смисъла на живота, смъртта, пре-

${ }^{1}$ Преводите от полски на български език са направени от авторката на статията.

Анна Каменска (1920-1985) поетеса, преводачка, издава над двадесет авторски стихосбирки. Посвещава на България редица свои творби - Анаксандър, Археология, Уличната тълпа в Пловдив, Сбогуване с България, Море и небе, Пътуване, Църква в Созопол, Бистрица и други. Носителка е на орден „Св. св. Кирил и Методий“ пьрва степен (1966). За превода на полски език на български народни песни и съставителството на сборника Oj, lesie, lesie zielony. Butgarskie pieśni ludowe (1956) получава наградата на българския ПЕН клуб (1959 г.). Преводачка и редакторка на издания с българска поезия: Ziemia goraca. Antologia współczesnej poezji butgarskiej (1968); Poezje wybrane. Wybór, wstęp (1972), Poczekaj słońce. Wybór poezji (1972) - преводи на избрани творби на Пейо Яворов и Дора Габе. Редакторка на поетически книги с избрани преводи на Иван Вазов Niegasnacego się nie zgasi. Wybór poezji (1976), на Блага Димитрова Kto się zatroszczy o ślepego bociana (1982) и други. 
минаващото време и човешката тленност. „[...] Какво е останало от тялото на Зевс/мощна фигура от въздух/опряна на единия си крак/затьнал в пясъка на земята..." [Kamieńska 1957: 49].

Човекът в историята, нейният бяг, времената и смяната на историческите епохи, които може би не се чувстват така осезателно в Полша, поради нейната относителна културна и историческа монолитност, провокират философските размисли на поетите от следвоенното поколение. България най-неочаквано се оказва отправна точка за ред важни метафизически търсения на няколко известни полски поети от втората половина на XX век. Историческата и литературната памет за България, колкото и да са отдалечени по време, смисъл, конкретни реализации, са активизирани в един общ дискурс, а именно - историчността, древността на страната и нейната култура, представи разгърнати от споменатите автори в съвременната полска поезия:

[...] Спяхме в римския камък/и в гръцката буква./И под спуснатия клепач на Византия/ Спяхме в усмивката на Анаксандър/който се намира в софийския музей./Спяхме под копитото на тракийския кон.../и в празния маслен светилник/и в ампулката от парфюм/с изветрял аромат... [Kamieńska 1999: 49].

Същевременно това поколение, което помни Втората световна война и е изпитало нейните ужаси и оскъдица, в следвоенните десетилетия, открива страната по съвсем различен начин. В стиховете на Анна Каменска, Ян Шпиевак, Ян Зих, Ян Баранович и други автори България е заключена в образа на непокътнатата от военния катаклизъм, благодатна земя на фона на следвоенната разруха. В мемоарите си Бележник 1973-1979 (изд. 1987 г.) Анна Каменска отбелязва в бележката от 3-ти октомври:

Черно море е вече есенно, бурно. Градини със златиста вече патина. Червенеят листата на лозите. Навсякъде висят смокини, бадеми, дюли, пъстроцветни тикви, сливи, лавър, които съвсем не се „люлеят”. Атмосферата на пустите плажове, есенна тъга... Балтийско море има по-красива плажна ивица, но тукашните високи брегове, екзотичната растителност, буйните градини, хубавите кръчми, добрите хора. [...] Тежки жълти дюли се търкулват в краката ми. Всичко това е незаслужен дар [Kamieńska 1987: 51].

В полската поезия се появява, може да се каже, цяло едно тематично направление, изграждащо образа на България, един неин „бранд”“ като южна страна (първата антология на съвременната българска поезия е озаглавена Горещза земя (Ziemia goraca), установен код на писане за България, внушаващ представата за своебразен рог на изобилието на Юга. Страната привлича поетите, както с древността си, в творбите им оживяват артефакти, места, фигури от българската антична и средновековна история, с цялата си южна екзотика, с каменния образ на българския свят, така и с богатството на земята и нейните дарове - грозде, дюли, бадеми, мушмули - плодове, многократно поетически споменавани, някои от които нямат даже наименования в полския език, и в крайна сметка също творят красотата и образа на аграрната култура на страната. Това е поколението творци изпитало смъртната опасност и лише- 
нията на войната, което открива в България една запазена и богата на красоти, изобилна страна, за която Ян Шпиевак създава обобщаващата метафора: „Земя раждаща камък, бадеми и грозде“ [Śpiewak 1999: 50].

В полската литература България битува в разнолики поетически дискурси. В културно-историческата памет на поляците срещаме спомена за българската средновековна княгиня Венцислава-Виола, който се радва на многогодишен интерес, пиетет и даже визуализация на някои факти от нейната биография под формата на исторически спектакъл на открито. За нейната личност като дукеса и регентка на Ополското княжество черпим сведения от хрониките на Ян Длугош (Ioannes Dlugossius 1415-1480)². Средновековният автор в своята написана на латински история Annales seu cronicae incliti Regni Poloniae (Годишници или хроники на славното Полско кралство) споменава в няколко изречения за търновската княгиня Венцислава-Виола. Виола е съпруга на княз Кажимеж I Ополски (1179-ок. 1229/30), от династията Пясти и фактически баба на полския крал Владислав Локиетек. Владетелят на ополската земя Кажимеж, около 1217/1218 г. участва в Петия кръстоносен поход и връщайки се от него, довежда за своя сыпруга Венцислава-Виола, която получава титлата дукеса на Ополе-Рачибож³. Длугош еднозначно отбелязва: Виола по народност е българка (Viola genere et natione Bułgara), без да определя дали нейната титла е княжеска. И по-нататък в бележката си средновековният историк допълва: Венцислава (Виола) се е омъжила през 1211 г., починала е на 7 октомври 1251 г. [Długosz 2009: 358-359] В различни исторически сведения тя фигурира като дукеса и регентка на Ополе-Рачибож (Oppeln-Ratibor, Principality in Silesia, 1233/34-38), родена в България ${ }^{4}$. За дъщерята на Кажимеж и Виола - монахинята Венцислава, хронистьт пише

2 Ян Длугош е полски хронист, свещеник, географ и дипломат, възпитател на синовете на Кажимеж Ягелонски. Той е автор на няколко съчинения на историческа тема, написани на латински език, между които Annales seu cronicae incliti Regni Poloniae (Годишници или хроники на славното Полско кралство), в които разказва историята на Полша от най-ранните векове на съществуването ѝ до 1480 г. Друго негово съчинение е описанието Banderia Prutenorum (Бойните знамена на войските на кръстоносиите от Прусия).

${ }^{3}$ В различни исторически сведения фигурира като дукеса и регентка на „Oppeln-Ratibor (Opole-Racibórz), Principality in Slesia, 1233/34-38. Княжеската двойка е имала 4 деца, Мешко Дебелия (1220-1246), Владислав, княз на Ополе (ок.1225-1282), Ефросина (1230-ок.12921294) и Венцислава - по-късно монахиня. Единствената бележка за нея е свързана със смъртта на баща ѝ, княз Кажимеж: „Погребали го в църквата на ордена на премонстрантките в арновонс, който князът пренесъл тук от Рибник заедно със своята дъщеря [...] монахиня в същия град“. След смъртта на съпруга си, Виола управлява самостоятелно като регентка Ополското княжество. По-късно то е опустошено от татарските орди на Бату-Хан, а през следващите години започват продължителни религиозни войни.

${ }^{4}$ Born in Bulgaria - d. 1251. After the death of her husband, Kazimierz she was regent for sons Mieszko II and Władysław, from 1233/1234 jointly with Henryk I Brodaty; 1230-1231 Regent Dowager Duchess Wiola, 1233/34-1238 Co-Regent. https://www.revolvy.com/main/index.php?s= Viola,\%20Duchess\%20of\%20Opole\&item_type=topic; https:/www.geni.com/people/цар-БОРИЛ/ 6000000008922626819; [madWorldwide Guide to Women in Leadership]. 
в главата Лето Господне 1236 на историческо си съчинение, споменавайки, че е притежавала „много добродетели и необикновена набожност“.

Историческият факт на идването на Венцислава-Виола в началото на XIII век от столицата на Второто българско царство, Търново, в силезийското княжество е пресъздаван в наши дни в няколко градчета в Западна Полша, разположени в околностите на Ополе, чрез фестивалните форми на масовата култура. Пример за това е историческият фестивал в Бобровники, където е показвана специална театрално-историческа постановка озаглавена Княгиня Виола пристига. В основата ѝ са залегнали реални исторически факти. През 1238 г., пътувайки със своята свита, Виола спира в Бобровники, признава на жителите му градски права и дава право на заселване. Историческите реконструкции в нашето съвремие стават все по-популярни, поради ренесанса на историческата памет и заменят успешно традиционните начини за отбелязване на събития и годишнини. По своята същност те залагат както на популяризирането на историята, така и на развлекателните функции на фестивалите и инсценизациите, провеждащи се на местата, където са се разиграли историческите събития. Подобни съвременни форми на популярната култура имат значение, тъй като привличат много млади хора и разпространяват историческото знание. В началото на шейсетте години на XX век, историкът Владислав Джиевулски ${ }^{5}$ обрьща внимание на сведенията дадени от Длугош за българския произход на Венцислава Виола в студията си Българка - княгиня на Ополе? [Dziewulski 1969: 159-182] По негово мнение Виола е била законна или извънбрачна дъщеря на цар Калоян или на неговия братовчед и наследник Борил. На същото мнение е и известният изследовател на генеалогичното дърво на династията Пяст - Кажимеж Яшински. [Jasiński 1977] Изворите за „българската дукеса“ и съвременните трансгресии по темата в общественото пространство ни отвеждат към разказа за славянското минало на западните полски земи, в по-широка перспектива представят континиуума между старите силезийски княжества и съвремеността. Без сьмнение този наратив подхранва и паметта за Виола. Подбрани факти от националната история или селектираната рецепция на чуждата култура в различни исторически периоди мощно се вписват или се отхвърлят от конкретните идеологически дискурси и обществени „нужди“, важни за даденото време. Историята на Венцислава Виола е вписана в полския следвоенен наратив, ополската дукеса функциони-

${ }^{5}$ Привържениците на теорията за българския произход на ополската княгиня свързват династическия брак на Виола и Кажимеж с участието на неизвестен полски княз, не споменат по име в историческите хроники, вероятно не се е числял към известните участници в Петия кръстоносен поход. Изследователите в повечето случаи идентифицират този владетел с Кажимеж I Ополски. Най-вероятно посредник при сключването на брака е бил унгарският крал Андрей II Унгарски. При връщането си от кръстоносния поход той сгодява своята дъщеря Анна Мария с българския цар Йоан Асен II, впоследствие - най-успешният и победоносен владетел на Второто българска царство. Вероятно тогава сродницата на царя Венцислава Виола е дадена за съпруга на Кажимеж, който се врьщал със свитата на унгарския крал от кръстоносния поход. 
ра в регионалното съзнание за малкото отечество. Дългогодишното ѝ битуване в споменатия контекст е свързано в немалка степен и с историческите представи, оформящи парадигмата за историческото славянско/полско наследство на западните ополски покрайнини, придобити отново от Полша след почти пет века, в резултат на международните договори след завършването на Втората световна война през 1945 г.

През осемдесетте години на XX век, в условията на силно политизиран и променен обществен климат, някои полски изследователи лансираха хипотези, че Виола е може би „русинка” или унгарка по произход, дъщеря на унгарския крал Бела III - игнорирайки важното историческо доказателство, оставено ни от Длугош, който еднозначно е посочил етническия произход на княгинята. [Swoboda 1980: 61-78] За връзките на Виола с България и византийския културен кръг, говорят и имената на нейните дыщери - Венцислава и Ефросина, които не са типични за полската именна система. Деветдесетте години на XX век поставиха разказа за Виола също в изменен дискурс. В политически план нямаше чак такава необходимост да се акцентира върху славянското наследство на западните полски територии. Особено след 1989 г. полският геополитически интерес трайно се насочи преди всичко към Централна и Западна Европа или към източните ѝ съседи (Украйна). Разнообразните реинтерпретации на миналото илюстрират промените в използваните дискурси.

Въпреки някои конюнктурни виждания и спорове около нейната личност, Венцислава-Виола продължава да живее в съвременната памет на поляците от региона, именно като българска княгиня и днес благодарение на историческите реконструкции и джендър проучванията върху средновековното общество тя е по-популярна от всякога. Българската княгиня е упомената на официалния сайт на град Ополе и Ополското воеводство. На нея са посветени стотици публикации в интернет и няколко книги, между които на Анна Побуг-Ленартович, професор в Историческия институт на Ополския университет: Energiczne, władcze, pobożne. Księżniczek i księżnych opolskich portret prawie własny (Opole 2016). Разказът за Виола се води с пиетет и уважение: „Княгиня Виола е била креативна жена, отговорна и амбициозна. Нейните съвременници са я възприемали като умен и твърд политик, а освен това се е занимавала и с благотворителна дейност“ [Pobóg-Lenartowicz 2016: 23]. В историята на това малко княжество, каквото е било Ополското, Венцислава-Виола оставя отпечатька на своята личност, в която се оглеждат най-добрите традиции и черти на владетелите от Второто българско царство - енергия, държавническо мислене, културотворческа мисия и меценатство. Запазеният печат на Виола е единственият владетелски печат, който са използвали ополските владетели през XIII в., секла е собствени монети и е имала собствена канцелария. Трябва да си представим съвсем различната културно-политическа ситуация през XII-XIII век, когато цивилизационните центрове са се намирали в Югоизточна и Южна Европа, за да разберем дейността и личността на княгиня Венцислава-Виола в контекста на чуждата 
страна и култура. По това време споменатото княжество, а и полското кралство са в културната и държавническа орбита на северния латински кръг, периферен за тогавашна Европа. Побуг-Ленартович сравнява образно културната ситуация на двете страни: детството на Виола е преминало в представителен каменен дворец, където само тронната зала на Царевец е била с размери 35 х 16 м, с три реда колони, а Кажимеж я довежда в княжески дом, фактически жилищно-отбранителна кула, изградена от дърво, представляваща четириъгьлник с размери 12 х 15 м. [Pobóg-Lenartowicz 2016: 38-46] Венцислава-Виола, ополска, калиска и руцка дукеса, предприема мащабно строителство като регентка, включително и на сакрални обекти. Както отбелязва Александър Вилкон: „Очевидно е, че полското средновековие не е имало такава културна и цивилизационна среда, ресурс, какъвто са притежавали страните, влизащи някога в състава на старата Римска империя“ [Wilkoń 1988: 19], което преимущество в ранното средновековие са имали българите и използвайки културния ресурс на Източноримската (византийска) империя създават развита държава, култура и урбанистика.

В Югозападна Полша, в специфичните условия на региона, княгиня Виола живее в локалната култура от близко петдесет години. Въпреки намаления интерес в последните десетилетия към „славянската опция“, ясно е, че благодарение на нея българската история се среща с полската. Историческите превратности, загубата на територии за определени периоди, подхранва носталгичната памет, която често е митологизирана (онирична), свързана със сакрализираното национално или локално пространство. От друга страна процесите на глобализация, атакувайки локалните традиции и памет, предизвикват антиглобализационен синдром, засилване и връщане към „корените“, свидетели сме на изключително оживление на локалността, на идеята за малките отечества. Днес Венцислава-Виола е включена трайно в съвременната полска популярно-историческа култура. Преди няколко години в проведения плебисцит на тема „Кои са най-известните жени от Ополе и региона?“, българската княгиня е поставена на първо място. Без съмнение историята, писана и неписана, текстовете и образите принадлежат към ключовите топоси на битуване и запазване на паметта. По сходен начин литературната памет е едно от местата, където България се среща с историята в поетическа форма. Рецепцията на българското може да бъде представена синтетично в пет художествени кода, които следвоенното поколение полски поети обособяват и използват за „българската тема“: историчността на страната; древна „каменна“ земя (камъкът е олицетворение на нейната история и природа); южна, гореща страна; изобилие от дарове на земята; природни красоти. Тези кодове в поетическите текстове на споменатите автори творят мрежи от значения, преплетени една с друга по такъв начин, че никоя не доминира над останалите. За разлика от идеалния текст на Ролан Барт, който няма начало и механизмите, които го задвижват са необхватни, без финален смисъл, полските поети вплитат в мрежи от значения конкретни екзистенциални въпроси, разположени в телеологичния хоризонт на познание. От 
красотата на местата и фрагментите на историята искат да изтрьгнат истината за човешкото битие и миналото, да ги спасят от метафизичната забрава, обобщавайки ги художествено и с помощта на българските мозайки.

\section{Библиография}

Assman A. (2013), Między historia a pamięcią. Antologia, red. i przeł. M. Saryusz-Wolska, WUW, Warszawa.

Baranowicz J. (1999), List z Butgarii, [w:] Anioł z Bojany. Wiersze o Butgarii. Antologia, Aspra, Warszawa.

Derrida, J. (1992), Kres człowieka, przeł. P. Pieniążek, [w:] Pismo filozofii, red. B. Banasiak, Kraków, s. 130-136.

Długosz J. (2009), Jana Długosza Roczniki, czyli kroniki stynnego Królestwa Polskiego 1140-1240, t. 5, ks. 5, 6, wyd. II, przeł. J. Mrukówna, Wydawnictwo Naukowe PWN, Warszawa.

Dziewulski W. (1969), Butgarka księżna opolską?, „Śląski Kwartalnik_Historyczny Sobótka“, t. 24, z. 2, s. 159-182.

Geertz C. (2005), Interpretacja kultur. Wybrane eseje, przeł. M. Piechaczek, Wydawnictwo Uniwersytetu Jagiellońskiego, Kraków.

https://www.geni.com/people/цар-БОРИЛ/6000000008922626819 [madWorldwide Guide to Women in Leadership]

https://www.revolvy.com/main/index.php?s=Viola,\%20Duchess\%20of\%20Opole\&item type=topic

Jasiński K. (1977), Rodowód Piastów śląskich, t. 3, nr 183, Piastowie opolscy, cieszyńscy i oświęcimscy, Wrocławskie Towarzystwo Naukowe: Dolnośląskie Towarzystwo Oświatowe, Wrocław.

Kamieńska A. (1957), Archeologia, [w:] Nad chmurami, Czytelnik, Warszawa.

Kamieńska A. (1987), Notatnik 1973-1979, Wydawnictwo W drodze, Poznań.

Kamieńska A. (1988), Notatnik 1965-1972, wyd. II, Wydawnictwo W drodze, Poznań.

Pobóg-Lenartowicz A. (2016), Energiczne, władcze, pobożne. Księżniczek i księżnych opolskich, portret prawie własny, Wydawnictwo Nowik, Opole.

Różewicz, T. (1998) Mozaika bułgarska z roku 1978, [w:] Zawsze fragment; Recycling, Wydawnictwo Dolnośląskie, Wrocław.

Swoboda W. (1980) Księżna kaliska Bułgarka? Przyczynek do rozbioru krytycznego Annalium Dlugosza, „Studia i Materiały do Dziejów Wielkopolski i Pomorza“, t. 3, s. 61-78.

Śpiewak J. (1999) Butgaria, [w:] Anioł z Bojany. Wiersze o Butgarii. Antologia, Aspra, Warszawa.

Wilkoń A. (1988), Średniowiecze, [w:] Okresy literackie, red. J. Majda, Wydawnictwa Szkolne i Pedagogiczne, Warszawa.

Андреев Й. (1997), История на Второто българско изарство, Издателство АБ, Велико Търново. 
Галя Симеонова-Конах

\title{
ABOUT THE BULGARIAN MOSAICS AND PRINCESS VENTSISLAVA VIOLA IN THE POLISH LITERARY AND CULTURAL MEMORY
}

\begin{abstract}
(Summary)
The author analyzes the presentations of the Bulgarian theme in Polish poetry and the popular culture (historical spectacles about Princess Ventsislava Viola in the Opole region, Poland). In Polish historical memory, the story of the Bulgarian Princess Ventsislava Viola (?-1251), the wife of Duke Casimir I, has been preserved in the Annals of Jan Długosz (Ioannes Dlugossius, 1415-1480).

Analysis of poetical works from the twentieth century by Tadeusz Różewicz, Anna Kamieńska, Jan Zych, Jan Śpiewak and other authors devoted to Bulgaria, considered in literary discourse, makes it possible to identify five codes of artistic interpretation: stone as the quintessence of Bulgaria, history and metaphysics, beauty, ancient and medieval archaeological monuments of the Bulgarian lands, the land of abundant harvest.
\end{abstract}

Key words: historical memory, popular culture, historical spectacles, Princess Ventsislava Viola of Bulgaria, codes of interpretation in Poetry, Polish Poets (the second half of the 20th C.) of Bulgaria, Tadeusz Różewicz 